\title{
The Effect of Combination Pranayama Yoga and Endurance Training Exercise on Peak Expiratory Flow (PEF) in Adult Asthmatic Patients
}

\author{
Akbar Nur ${ }^{1}$, Kusnanto Kusnanto², Muhammad Amin ${ }^{3}$, Muhammad Sajidin ${ }^{4}$, Ninuk Dian \\ Kurniawati ${ }^{2}$, Arief Bakhtiar ${ }^{3}$ \\ ${ }^{1}$ Nursing Science Program, Andini Persada College of Health Sciences, Mamuju, Indonesia \\ ${ }^{2}$ Faculty of Nursing, Universitas Airlangga, Surabaya, Indonesia \\ ${ }^{3}$ Faculty of Medicine, Universitas Airlangga, Surabaya, Indonesia \\ ${ }^{4}$ Nursing Science Program, Bina Sehat PPNI Institute of Health Science, Mojokerto, Indonesia \\ Corresponding email:akbarskep@gmail.com
}

Submitted: 27-04-2020 Accepted: 15-07-2020 Published: 01-08-2020

\begin{abstract}
Pranayama Yoga can help improve breathing, and improve calm and also relieve stress. Endurance training can increase lung capacity, improve fitness, and relax the body. However, the combination of pranayama yoga and endurance exercises has never been done in asthma patients. The purpose of this study was to analyze the combination of pranayama yoga exercises and endurance exercises for Increased Peak Forced Expiration Flow. The design of this study was Quasy Experiment with a pretest-posttest control group design, the location of the study was in the pulmonary clinic of Universitas Airlangga Hospital and Haji General Hospital in Surabaya, East java. Respondents were selected by purposive sampling techniques in accordance with inclusion criteria with a total of 72 respondents. Peak Expiration Flow is measured from forced vital capacity or The peak expiratory flow (PEF) is the maximum flow obtained within the first 200 milliseconds of a forced expiratory maneuver after inhalation to total lung capacity (TLC). The intervention group was given a combination exercise by doing pranayama yoga and endurance exercise for 6 weeks, 2 x per week, 51 minutes for each training session. Pranayama yoga combination exercises and endurance exercise using trainer instructors and modules. FPEF and asthma control were measured every week for 6 weeks. The results showed a significant difference in the level of FPEF and asthma control before and after 6 weeks of interventions combination of pranayama yoga and endurance exercise in the intervention group obtained significance values $(p<0.05)$ with $p=0.000$ and asthma control in the intervention group $(\mathrm{p}<0,05)$ with $\mathrm{p}=0.000$ the results of the research shows that by practicing pranayama yoga and endurance exercise can improve FPEF and asthma control. Pranayama yoga and endurance exercise can be used as an complementary therapy in supporting pharmacological therapy to improve FPEF and control asthma.
\end{abstract}

Keywords: Asthma, endurance exercise, PEF, pranayama yoga. 
Akbar Nur: The Effect of Combination Pranayama Yoga and Endurance Training Exercise on PEF

\section{Introduction}

Asthma is a chronic airway disease that is a public health problem in various countries. Asthma can be mild and does not interfere with activities, but can be sedentary and disrupt activities and even daily activities. The prevalence of asthma has risen sharply and asthma is now known as the most frequent cause of disability, requires large costs and preventable illness (Atmoko, Faisal, Bobian, Adisworo, \& Yunus Faisal, 2011; Yang ZY, Zhong HB, Mao C, Yuan JQ, Huang YF, Wu XY, Gao YM, 2016).

Asthma was once thought to be a disease caused by smooth muscle spasm, now asthma is a complex inflammation that controls clinical and physiological changes. Asthma sufferers are people who are dependent on drugs and breathing aids that require expensive costs. As a heterogeneous disease, asthma is usually characterized by chronic airway inflammation. Typical symptoms of asthma are wheezing, shortness of breath, chest tightness, and coughing that vary from time to time and experience limited expiratory airflow (GINA, 2018).

According to the World Health Organization (WHO, 2018), asthma sufferers of 235 million people, the death rate from asthma in Indonesia reached 24,773 people or about $1.77 \%$ of the total population of the population, this data also puts Indonesia at number 19 in the world regarding asthma deaths. GINA (GINA, 2018), an estimated 300 million people suffer from asthma. The average global prevalence of asthma ranges from $1 \%$ to $18 \%$ of the population of various countries. The number of asthma sufferers in the world reaches 300 million people. This number is expected to continue to increase to 400 million by 2025 . The prevalence of asthma sufferers in Indonesia is $4.5 \%$ with the highest incidence occurring in women at $4.6 \%$. The highest prevalence of asthma sufferers was found in Central Sulawesi (7.8\%), followed by East Nusa Tenggara $(7.3 \%)$, in Yogyakarta $(6.9 \%)$, and East Java with an asthma prevalence of $(5.1 \%)$ (Badan Penelitian dan Pengembangan Kesehatan, 2013).

Efforts made by health workers at Universitas Airlangga Hospital and Haji
General Hospital in Surabaya, provide information about asthma such as avoiding stress, cold weather, dust, cigarettes, and other allergens and providing asthma medication but still do not show an increase in PEF and control asthma.

Asthma symptoms can be controlled by pharmacological and non-pharmacological therapies, pharmacological therapies, for example, administering lozenges and inhalation therapy. Providing pharmacological therapy aims to relax bronchial smooth muscle, increase mucociliary cleansing and modulate the release of allergen mediators from mast cells, but even though the patient has taken asthma treatment, there are still $50 \%$ of patients with the uncontrolled state, $30 \%$ partially controlled, $20 \%$ fully controlled (20\% controlled) (Julvainda Eka Priya Utama, 2018; Quirt, Hildebrand, Mazza, Noya, \& Kim, 2018). This shows that most patients are not controlled, despite asthma treatment. Until now, health workers continue to conduct research related to pharmacological and non-pharmacological therapies. Non-pharmacological therapy is used as a support for pharmacological therapy to increase peak expiratory flow (PEF) and the degree of asthma control. One of the nonpharmacological therapies that can increase the peak flow of forced expiration and asthma control is pranayama yoga practice and endurance exercise.

One of the non-pharmacological therapies that can increase Peak expiratory flow (PEF) and asthma control is yoga pranayama and Endurance training exercise. Yoga has been recommended for pulmonary rehabilitation programs and in addition to physical therapy in rehabilitation programs and has been shown to improve mind and body coordination. Yoga is called a "low-impact" sport that can be tailored to the needs and abilities of its practitioners so that it is suitable for anyone including asthmatics through asanas (yoga postures) and pranayama (breathing techniques). Short-term studies on yoga practice have reported an increase in pulmonary physiological parameters, increased diffusion capacity, reduced rates of stress due to tightness and improved quality of life (Cramer, Posadzki, Dobos, \& Langhorst, 2014; Liu et al., 2014). 
Breathing exercises in yoga can activate the hypothalamus part of the brain's response which can affect good emotions and have an effect on asthmatics (Chandra, 1994; Liu et al., 2014; William Fernando BenavidesPinzón, 2017). In addition to Pranayama Yoga that can be given to asthma patients, there are epidemiological studies that endurance exercise can extend life expectancy and reduce the risk of chronic diseases. The effects of endurance exercise in addition to enlargement of muscle fibers, mitochondria which will increase the source of muscle energy, makes the muscles not easily tired. This is by the needs of asthma patients who tend to get tired quickly, causing shortness resulting in reduced life activities. This adaptation results in better health reduce the risk of morbidity and mortality and improve the quality of life (Abirami \& Raj, 2013; Khotimah, 2013; Nizet et al., 2009; Safdar et al., 2011).

Exercise activity can be done by anyone, including asthmatics. Many asthmatics may feel afraid of doing exercise activity because exercise is also one of the triggers of an asthma attack, Rogger Catz of the University of California states that about $80 \%$ of asthma sufferers are caused by allergies and 40\% fever, including asthma caused by exerciseinduced asthma (EIA). However, EIA sufferers do not give up doing sports because doing good exercise can reduce the relapse and dependence of asthma medication (Côté, Turmel, \& Boulet, 2018; Wijaya, 2015).

Several studies have proven several interventions given to asthmatics including asthma exercises, deep breathing, Buteyko, upper body exercises, and yoga pranayama as one type of intervention that can be done to protect and improve respiratory health helps to improve asthma and increase peak expiratory flow (PEF). However, it is not yet known the effectiveness of the combination of pranayama yoga exercises and endurance training exercise in increasing the Peak Expiratory Flow (PEF).

The combination of pranayama yoga practice and endurance exercise is expected to increase the peak flow of forced expiration and asthma control through bronchial smooth muscle relaxation and decreased respiratory frequency (Eichenberger, Diener, Kofmehl,
\& Spengler, 2013; Putra, Sriyono, \& Yasmara, 2017). At present there is still limited research on this matter, so researchers are interested in analyzing the effect of a combination of pranayama yoga exercises and endurance exercise on increasing the Peak Expiratory Flow (PEF) and asthma control. Observing the high morbidity and mortality due to asthma that increases from year to year is a special concern from the world of health, one of which is in nursing that can provide independent intervention as a companion to pharmacological therapy. The objective of the study is to analize the effect of a combination of yoga pranayama and endurance exercise on Peak Forced Expiration Flow and control asthma.

\section{Method}

The design of the research was quasiexperimental with pretest-posttest control group design. This study uses a sampling technique in which samples are taken based on purposive sampling. This study uses respondents from 2 hospitals, for the intervention group conducted at Airlangga University Hospital and the control group was conducted at the Haji General Hospital in Surabaya. This was done so that respondents in the intervention group and the control group did not meet each other and did not tell each other about the interventions that had been given during the research process so that the research was not biased.

The target population in this study were adult patients who were diagnosed with asthma in the pulmonary clinic at Universitas Airlangga Hospital and Haji General Hospital in Surabaya, using history taking, physical examination, and spirometry examinations that had undergone outpatient treatment. In this study, 2 were excluded and 1 person refused to participate in this study. A total of 76 subjects consisting of 20 men and 56 women, 4 subjects in the control group who had dropped out of school because they could not follow the exercise regularly on a schedule. So that the total sample used in this study was 72 subjects.

Inclusion criteria in this study were asthma patients aged 17-60 years, good 
oral communication, asthmatics were stable and able to sit and stand without the help of others and tools. While the exclusion criteria are, asthma sufferers in attacks, patients with shortness of breath due to complications of other diseases, patients with permanent physical disorders of the neck, chest, and upper extremities.

Peak Expiratory Flow measured from forced vital capacity or The peak expiratory flow (PEF) is the maximum flow obtained within the first 200 milliseconds of a forced expiratory maneuver after inhalation to total lung capacity (TLC). Peak Expiratory Flow was measured using a peak flow meter performed 3 times and the highest value was taken in each measurement while asthma control was measured using an asthma control test conducted before and after pranayama yoga practice and endurance training exercise for 6 weeks. The intervention group was given a combination exercise by doing pranayama yoga and endurance exercise for 6 weeks, 2x per week for 51 minutes for each training session. One-time joint training using the instructor and one time self-training at home using the module while still being monitored by family members and researchers by recording pranayama yoga exercises and endurance training exercises that have been done and each participant sends videos and documentation images to the group Whatsapp has been made by researchers. Pranayama yoga combination exercises and endurance exercise using instructor trainers and modules. The control group was conducted at the Haji General Hospital, by continuing to follow the treatment by the standard operational procedures (SOP) at the pulmonary clinic of the Haji General Hospital in Surabaya and was not allowed to practice yoga pranayama and endurance exercise while participating in the study. After the research is completed, the control group is given a module and exercises together with both the control group and the intervention group conducted at the Lake of Airlangga University or the Airlangga University Hospital.

The steps of the Pranayama yoga and Endurance Training Exercise technique: 1) The pose of sukhasana, 2) Padmasana, 3) Sidhasana, 4) Vajrasana. Next to do pranayama breathing consisting of; 1)
Dhirgaswasam 5 minutes 2) Ujjayi 5 minutes 3) Kapalabhati 5 minutes 4) Anuloma viloma 5 minutes 5) Sitali 5 minutes 6) Sitkari 5 minutes. After doing yoga exercises for about 30 minutes, participants are encouraged to take a 5-minute break before doing Fartlek exercises for 21 minutes, by way of; warmup exercises consisting of 20 seconds lunges, side lunges 20 seconds, squat 5 seconds, high knee 10 seconds. Then continue the exercise for 5 minutes, jogging 2 minutes, walking 5 minutes, jogging 2 minutes. Walk for 5 minutes. After ending the exercise it is recommended not to sit down immediately but to do the cooling consisting of; Hamstring stretch 20 seconds, Calf stretch 20 seconds, Forward bend 20 seconds. To prevent/ overcome the recurrence of subjects during pranayama yoga practice and endurance exercise or exercise-induced asthma (EIA), the researchers first coordinated with the supervisor and the responsible physician at the Hospital Universitas Airlangga and Haji General Hospital in Surabaya to prepare for inhaler drug therapy, oxygen, and warm-up before exercise and conditioning after doing the exercise. Subjects who experienced a recurrence during exercise then it is recommended not to continue training. In this study using pranayama yoga practice instruments and endurance exercise using informed consent sheets, Standard Operating Procedures (SPO), instructors, training modules and respondent characteristics sheets. In the measurement of the Peak Expiratory Flow Rate (PEFR) using, Peak Flow Meter, the respondent characteristic sheet that contains questions about the respondent's identity, including the initial name, gender, age, level of education, height, length of time suffering from asthma and the value of Forced Peak Expiratory Flow ( PEFR ) while for the assessment of the level of asthma control using ACT (Asthma Control Test) there are several things that are assessed namely the intensity of asthma recurrence in doing daily work, experiencing shortness of breath, waking up at night, the use of drugs and the level of asthma control which includes controlled asthma, partially controlled and uncontrolled. This study will evaluate the Pre-Post Forced Peak Expiratory Flow (FPEF) and asthma control by using 
the achievement sheet of the Forced Peak Expiratory Flow (PEFR) asthma control observation sheets before and after pranayama yoga practice and endurance exercise.

Statistical test using the Wilcoxon test in the Peak Expiratory Flow Rate (PEFR) where the treatment group showed a significant difference between the PEFR. in the control group showed that there was no significant difference between the pre-test and posttest PEFR. In Prediction Peak Expiratory Flow (PEF) (\%) using paired T-test where the treatment group showed a significant difference between PEFR (\% predicted) before and after pranayama yoga combination training and endurance training exercise in the control group showed no significant difference between APE ( $\%$ predicted) before and after. For the analysis of asthma control using the Wilcoxon test where the treatment group showed a significant difference between asthma control before and after the practice of pranayama yoga combination and endurance exercise. Paired T-test results in the control group showed no significant difference between asthma control before and after. MANOVA test results obtained a significance which indicates that there are differences in the average PEFR and asthma control values in the treatment and control groups. This shows that there is an effect of pranayama yoga combination training and endurance exercise in asthma patients.

Ethical approval was issued by the Airlangga University Hospital Research Ethics Commission with Number: 197 / KEH / 2018 on December 11, 2018, and the Haji General Hospital with Number:. 073/07 / KOM.ETIK / 2019 on 7 February 2019.

\section{Results}

Table 1 Respondent's Characteristic

\begin{tabular}{|c|c|c|c|c|c|}
\hline \multirow[t]{2}{*}{ Characteristic } & \multicolumn{2}{|c|}{$\begin{array}{c}\text { Treatment Group } \\
(\mathrm{n}=34)\end{array}$} & \multicolumn{2}{|c|}{$\begin{array}{c}\text { Control Group } \\
(\mathrm{n}=38)\end{array}$} & \multirow[t]{2}{*}{$\mathbf{P}$} \\
\hline & f & $\%$ & f & $\%$ & \\
\hline \multicolumn{6}{|l|}{ Age years } \\
\hline $18-25$ & 3 & 8.8 & 1 & 2.9 & 0.001 \\
\hline $26-35$ & 5 & 14.7 & & 14.7 & \\
\hline $36-45$ & 11 & 32.4 & 5 & & \\
\hline $46-60$ & 15 & 44.1 & 32 & 68.1 & \\
\hline \multicolumn{6}{|l|}{ Education } \\
\hline No school & 1 & 2.9 & 1 & 2.9 & 0.331 \\
\hline $\begin{array}{l}\text { Junior High } \\
\text { School }\end{array}$ & 6 & 17.6 & 19 & 50.0 & \\
\hline High School & 14 & 41.2 & 11 & 34.2 & \\
\hline College & 13 & 38.2 & 7 & 18.4 & \\
\hline \multicolumn{6}{|l|}{ Occupation } \\
\hline PNS & 3 & 8.8 & 3 & 8.8 & 0.393 \\
\hline Enterpreneur & 5 & 14.7 & 11 & 28.9 & \\
\hline Others IRT & 26 & 76.5 & 24 & 63.2 & \\
\hline \multicolumn{6}{|l|}{$\operatorname{sex}$} \\
\hline Male & 5 & 14.7 & 11 & 68.8 & 0.210 \\
\hline Fimale & 29 & 85.3 & 27 & 79.4 & \\
\hline \multicolumn{6}{|l|}{ Genetik } \\
\hline No & 10 & 29.4 & 10 & 26.3 & 0.567 \\
\hline Yes & 24 & 70.6 & 28 & 73.7 & \\
\hline
\end{tabular}


Akbar Nur: The Effect of Combination Pranayama Yoga and Endurance Training Exercise on PEF

Table 2 The value of the PEFR, APE (\%) prediction, asthma control in the treatment groups and the control groups

\begin{tabular}{llcccc}
\hline \multicolumn{1}{c}{ variabel } & \multicolumn{1}{c}{ Groups } & $\begin{array}{c}\text { Pre-Test (Mean } \\
\pm \text { SD) }\end{array}$ & $\begin{array}{c}\text { Post-Test } \\
(\text { Mean } \pm \text { SD) }\end{array}$ & Delta $(\boldsymbol{\Delta})$ & P Value \\
\hline PEFR (L) & Treatment & $280.00 \pm 56,622$ & $350.88 \pm 44.064$ & 70.88 & 0.0001 \\
& control & $241.05 \pm 43.483$ & $240.79 \pm 47.555$ & 0.26 & 0.813 \\
APE (\%) & Treatment & $64.85 \pm 16373$ & $82.68 \pm 11422$ & 17.83 & 0.000 \\
PREDIKSI & Control & $57.61 \pm 15559$ & $57.42 \pm 15742$ & 0.019 & 0.868 \\
\multirow{2}{*}{ Asthma Control } & Treatment & $15.38 \pm 3.574$ & $21.32 \pm 1,249$ & 5.94 & 0.0001 \\
& control & $14.68 \pm 2.451$ & $15.61 \pm 2.521$ & 0.93 & 0.013 \\
\hline
\end{tabular}

Table 3 Distribution of Asthma Control Levels in the Treatment groups and Control Groups

\begin{tabular}{lcccccccc}
\hline \multirow{2}{*}{ Asthma Control } & \multicolumn{3}{c}{ Treatment Groups } & \multicolumn{3}{c}{ Control Groups } \\
\cline { 2 - 9 } & Pre-test & \% & Post-test & \% & Pre-test & \% & Post-test & \% \\
\hline Not controlled & 29 & 85,3 & 1 & 2,9 & 38 & 100 & 36 & 94,7 \\
Partially Controlled & 5 & 14,7 & 33 & 97,1 & 0 & 0 & 2 & 5.3 \\
Fully Controlled & 0 & 0 & 0 & 0 & 0 & 0 & 0 & 0 \\
\hline
\end{tabular}

Table 4 Results of multivariate analysis of a combination of pranayama yoga exercises and endurance exercise in the treatment groups and the control groups

\begin{tabular}{lccccccc}
\hline Variable & $\mathbf{N}$ & \multicolumn{4}{c}{ Box Test } & \multicolumn{2}{c}{ P value } \\
\cline { 3 - 7 } & & Box M & F & df 1 & df 2 & Lavene & $\begin{array}{c}\text { pillai's } \\
\text { trace }\end{array}$ \\
\hline PEFR & 72 & 0.000 & 6.091 & 6 & 3.430 & 0.373 & 0,0001 \\
Asthma & & & & & & 0,001 & \\
Control & & & & & & & \\
\hline
\end{tabular}

Table 1 shows that the age characteristics of respondents by age, the majority of respondents in the treatment group and the majority of the control group were in the age range 46-60 years are $15(44.1 \%)$ in the treatment group and $32(68.1 \%)$ in the control group which is the age category early elderly and late elderly. Age demographic data of respondents from both groups showed variants of inhomogeneous data with a value of $p=0.001$. this is because the age distribution in the two groups is not normally distributed and also the age factor affects lung function in a person. Regression test results obtained an R Square value of 0.06 meaning $0.6 \%$ PEFR and asthma control is influenced by age with a value of $p=0.526$ so it can be concluded that the age group of respondents did not have a significant relationship. On the characteristics of the education level of respondents in the treatment group, the majority were middle educated $14(41.2 \%)$ and in the control group, the majority were elementary education as many as 19 subjects $(50.0 \%)$. The characteristics of work in the treatment and control group were mostly as IRT / other, in the treatment group were 26 subjects $(76.5 \%)$ and the control group was 24 $(63.2 \%)$. Sex characteristics in the two groups were majority female, in the treatment group were $29(85.3 \%)$ women while in the control group were 27 (79.4\%). Characteristics of respondents based on family history of asthma (genetic) in the treatment group were 24 subjects $(70.6 \%)$ and the control group was 25 subjects $(73.5 \%)$ who had a family / genetic history of asthma.

Table 2 After a combination of pranayama yoga exercises and endurance exercise for 6 weeks, the mean PEFR value of the posttest $350.88 \pm 44.064$ in the treatment group obtained a delta value of $70.88(\mathrm{~L})$. Wilcoxon 
test results in the treatment group showed that there were significant differences between the PEFR before and after the pranayama yoga combination exercise and endurance exercise with a value of 0.001 (p $<0.05$ ). After being evaluated for 6 weeks, the mean post-test score was $240.79 \pm 47.555$ in the control group, the delta value was 0.26 (L). Wilcoxon test results in the control group showed that there was no significant difference between the APE pre-test and post-test with a value of $0.813(\mathrm{p}<0.05)$. In PEFR (\% prediction) in the treatment group, the mean PEFR prediction value was 64.85 $\pm 16373 \%$ and post-test $82.68 \pm 11422 \%$ and delta value of $17.83 \%$. Paired T-test results in the treatment group showed that there was a significant difference between PEFR $(\%$ prediction) before and after the combination practice of pranayama yoga and endurance exercise with a value of $0,000(p<0.05)$. In the control group PEFR mean ( $\%$ predicted) pre-test $57.61 \pm 15559 \%$ while post-test 57.42 $\pm 15742 \%$ delta value $0.019 \%$. The results of the paired T-test in the control group showed no significant difference between PEFR ( $\%$ predicted) before and after with a value of $0.868(\mathrm{p}<0.05)$. In the control group, the mean pre-test value was $15.38 \pm 3,574$ asthma control and after a combination of pranayama yoga exercises and endurance exercise for 6 weeks the post-test value was $21.32 \pm 1,249$ delta value of 5.94. Wilcoxon test results in the treatment group showed that there were significant differences between asthma control before and after the combination practice of pranayama yoga and endurance exercise with a value of $0,000(p<0.05)$. In the control group, the mean value of asthma pre-test control was $14.68 \pm 2.451$ while in the post-test $15.61 \pm 2.521$. the control group obtained a delta value of $0.93 \%$. Paired T-test results in the control group showed no significant difference between asthma control before and after with a value of 0.013 $(\mathrm{p}<0.05)$.

Table 3 shows that in the treatment group, the total pre-asthma control scores of subjects in the uncontrolled category were $29(85.3 \%)$ subjects. At post asthma control, it showed that the subjects were partially controlled by $33(97.1 \%)$ subjects and there were no subjects whose asthma was fully controlled
$(0 \%)$. In the control group, all pre-asthma control values were in the uncontrolled category 38 subjects $(100 \%)$ in the postasthma control were only $2(5.3 \%)$ partially controlled subjects and 36 (94.7) subjects were still in the uncontrolled asthma criterion.

Table 4 shows that testing the variancecovariance similarity individually for each variable shows a Box test value of 0.000 , which means that the variance-covariance in all variables is not the same for each group. So that in making decisions statistical test results can be seen in Pillai's trace. Manova test results obtained a significance value of $\mathrm{P}<0.0001(\alpha 0.05)$ which indicates that there are differences in the average PEFR and asthma control values in the treatment and control groups. This shows that there is an effect of pranayama yoga combination training and endurance exercise in asthma patients.

\section{Discussion}

\section{Peak Expiratory Flow (PEF)}

The peak flow of forced expiration is the highest point that can be reached during maximum expiration. In the event of asthma, there is great resistance to airflow, especially during expiration, when a person expires to reach a maximum flow where the flow cannot be increased even with a maximum increase in power (Moore \& Castro, 2017).

Airways that have decreased space cause the maximum expiratory flow to also be reduced. Maximum expiration can be achieved if there is no worsening of breath and reduction of space in the respiratory tract (Hall, 2015). In the treatment group, the majority of subjects experienced an increase in the post- PEF score.PEF value measurement is done once every week after doing a combination of pranayama yoga exercises and endurance exercise for 6 weeks, performed 3 (three) times the examination and the highest value was taken in each measurement. In the treatment group, some subjects during the initial PEFR assessment until week 3 had not yet seen an increase in FPEF. This is in line with the research presented by (Begum \& Hussain, 2013; Kushartanti, 2013; Eleckuvan, 2014; Parmar 
\& Nagarwala, 2014).

States that yoga interventions and effective end endurance training exercise are given at least 6 weeks of intervention with a frequency of exercise 3 times a week. So that in the 4th and 5th week, there was an increase in FPEF value. The increase in FPEF occurred significantly until the end of week 6 . The increase in the peak flow of forced expiration shows that the pranayama yoga practice and endurance exercise that is done can affect the increase in FPEF value. The increase in FPEF in the treatment group occurred at all ages but the majority of the increase in FPEF occurred in the 4th to 6th week of the intervention. Characteristics of subjects who experience an increase in PEF are relatively diverse ranging from the level of education, age, occupation, gender, and genetic / family history of asthma.

This is due to the APE ( $\%$ predictions) of the control group The difference in the median PEF and PEF predictions of the intervention group is greater when compared to the control group. All subjects experienced an increase in PEFR and FPEF scores (\% predicted) in the intervention group. This is because RSUA doctors and nurses provide pharmacological therapy and health education to asthma patients undergoing outpatient therapy at RSUA Lung Poly. In addition, subjects also received an intensive assistance program that is a combination of pranayama yoga and endurance exercise. So it can be concluded that procedural treatments at the polyclinic of pulmonary disease and interventions combination of pranayama yoga exercises and endurance exercise show more improvement in one pulmonary function, namely an increase in forced expiratory peak flow (FPEF) and APE (\% predicted).

Increased PEFR and PEF values $(\%$ predicted) in asthma patients indicate the patient has a good prognosis. This is due to lung repair. Improved pulmonary physiology shows the achievement of one of the outcomes in the implementation of nursing care. In this case, the patient is able to perform selfcare by doing pranayama yoga exercises and endurance exercise independently so that an increase in the value of PEF.

In this study, a combination of pranayama yoga exercises and endurance exercise is carried out for 6 weeks and done 2 times a week, pranayama yoga exercises and endurance exercises are done 1 (one) time with group/group exercises using instructors (trainers) and 1 (one) time carried out independently at home with the duration of exercise required, namely; pranayama yoga exercises were carried out for 35 minutes and endurance exercises were carried out for 21 minutes.

The results of this study are in line with other studies which show that pulmonary rehabilitation will get very optimal results if done as early as possible (after the patient has been diagnosed with asthma by a doctor), one form of pulmonary rehabilitation in asthma patients is by giving pranayama yoga breathing exercises. Pranayama Yoga is a breathing exercise with slow and deep breathing techniques, using diaphragm muscles, allowing the abdomen to rise slowly and the chest to fully expand. Yoga is a method of physical and mental training for all ages. Yoga provides relaxation to the body, blood circulation, and control of breathing. Yoga is very good for asthmatics (Agnihotri, Kant, Kumar, Mishra, \& Mishra, 2016; Agnihotri, Kant, Mishra, \& Singh, 2016; Kristina Zaičenkovienè1,Roma Aleksandravičienè1, Stasiulevičienè1, \& Lithuanian, 2013).

Yoga shows beneficial effects for people with chronic asthma such as reducing asthma medication, increasing exercise capacity, increasing FEV1, functional capacity and asthma control (Cebrià I Iranzo, Arnall, Camacho, \& Tomás, 2014). Research conducted on asthma patients shows highly statistically significantresults on allpulmonary physiology parameters. Pranayama yoga given to the yoga group for 6 weeks of practice showed a significant increase in FEV1 and PEFR in the pulmonary physiology tests of asthmatics who had performed pranayama yoga (Parmar \& Nagarwala, 2014; Shyam Karthik, Chandrasekhar, Ambareesha, \& Nikhil, 2014).

The effect of yoga obtained in this study is related to deep breathing techniques (pranayama) and meditation which causes a reduction in the frequency of breathing. This can modulate airway reactivity, increase breathing sensation through regulation of breathing patterns, reduce oxygen 
consumption, reduce the incidence of hypoxia and hypercapnia so that blood oxygenation is better without increasing ventilation, increase respiratory endurance and muscle strength and modulate autonomic function with decreased heart rate when resting and sympathetic activity (Bonura, 2007; Sindhu, 2015).

Pranayama is a breathing technique in ancient yoga. Pranayama integrates the mind and body and is focused on bodily sensations. Pranayama directly provides benefits to various body functions positively. Pranayama consists of (1) regular, slow and strong inspiration for a longer duration during exercise, which causes the strengthening of the breathing muscles, (2) increases expiratory power and decreases resistance to airflow in the lungs (3) increases holding time breath according to the ability of participants (Fulambarker et al., 2012; Shankarappa, Prashanth, Annamalai, \& Varunmalhotra, 2012).

In addition to pranayama yoga that can be given to asthma patients, epidemiological studies are stating that endurance exercises prolong life expectancy and reduce the risk of chronic diseases. The effect of endurance exercise besides enlargement of muscle fibers, mitochondrial enlargement also occurs which will increase the energy source of muscle work, so the muscles do not get tired easily. This is following the needs of asthma patients who tend to get tired quickly, causing shortness resulting in reduced life activities. This adaptation results in better health reduce the risk of morbidity and mortality and increase the quality of life (Chen, Tsai, Liou, \& Chan, 2017; Khotimah, 2013; Nizet et al., 2009).

Exercise is a very good way to increase the vitality of lung physiology. Exercise stimulates deep breathing and causes the lungs to expand so that the input of oxygen released into the blood increases and more carbon dioxide is released. If a person has more oxygen volume, the blood circulation is better, so that the muscles get more oxygen and can do activities without feeling tired (Ahmed, Mohamed, \& Hashem, 2011; Kushartanti, 2013; MuthEffectivenessu Eleckuvan, 2014).

In this study, the treatment group was given a combination of pranayama yoga exercises and endurance exercise. In this case, endurance exercise is given by doing jogging fartlek for 21 minutes consisting of; 1-minute warm-up exercise, walk 15 minutes, jogging 4 minutes and cool down 1 minute. By doing fartlek exercises by walking and jogging, the principle of fartlek training is running with various variations. This means that it can measure the desired running speed while doing the exercise as desired and also adjusted the conditions / practical abilities according to Sukardiyanto in the study (Kushartanti, 2013). Fartlek training is a part of endurance exercise that can increase lung capacity and increase respiratory muscles so that lung elasticity can be maintained. These conditions can open up lung space that can be used by alveoli in gas exchange. Fartlek can also stimulate sympathetic nerves in the respiratory muscles to excrete norepinephrine and epinephrine to bind to $\alpha$ receptors that cause the respiratory muscles to contract (Suryantoro, Isworo, \& Upoyo, 2017; Udayani \& Amin, 2019).

\section{Asthma Control Level}

Assessment of the level of asthma control using the ACT (Asthma Control Test), several things are assessed namely the intensity of recurrence of asthma in doing daily work, experiencing shortness of breath, waking up at night, the use of drugs and the level of asthma control. In some questions on ACT related to exacerbation/recurrence of asthma, which is a process of repeated attacks due to hyper-responsive immune cells such as mast cells, eosinophils and $\mathrm{T}$ lymphocytes, mast cells, macrophages, dendritic cells, and myofibroblasts to certain stimuli causing symptoms of shortness of breath, wheezing and coughing as a result of narrowing of the airway (Ghebre et al., 2015; Grzela et al., 2015). The results of this study indicate that pranayama yoga exercises and endurance training exercise are effective in asthma patients to improve asthma control. Asthma cannot be cured but can be controlled with proper management and management. This study is in line with other studies that show that the goal of asthma control is to reduce the frequency of asthma attacks, improve inflammation of the respiratory tract and 
Akbar Nur: The Effect of Combination Pranayama Yoga and Endurance Training Exercise on PEF

increase physical activity and pulmonary physiology (Baines et al., 2014).

Asthma control is generally divided into 2 namely controlled and uncontrolled. In the ACT (Asthma Control Test) assessment the classification of asthma control was divided into 3 , which were fully controlled with a score of 25 , partially controlled 20 24 and uncontrolled with a score of $<19$. In the category of partially controlled asthma control levels included in the classification of controlled asthma, it is related to individual efforts to achieve optimal asthma control that is fully controlled (Atmoko et al., 2011; Cramer, Lauche, \& Dobos, 2014; Katerine, Medison, \& Rustam, 2014).

The goal of asthma control is to reduce the frequency of asthma attacks, improve inflammation of the respiratory tract and increase physical activity and pulmonary physiology and also improve the quality of life which is also an important component in the management of asthma (Cramer, Lauche, et al., 2014; Shyam Karthik et al., 2014). Yoga exercises given for 2 months to asthma patients have an increase in forced vital capacity (FVC), forced expiratory volume in 1 second (FEV1), peak expiratory flow rate (PEF) (Agnihotri, Kant, Mishra, et al., 2016; Soni, Munish, Singh, \& Singh, 2012).

If people with asthma are very unfit, then the exercise program can be started by walking, because this exercise has lower asthma and prepares the muscles, for training with a higher intensity in the future. If the level of fitness increases, especially in the case of the musculoskeletal system, then the intensity of the exercise can be increased by conducting a low-level interval training consisting of walking and jogging (Wijaya, 2015). Endurance training exercise aims to improve the efficiency and capacity of the oxygen transport system. Endurance training which means to build, restore, or maintain the condition of one's body so that it is very good for asthmatics (Khotimah, 2013).

In addition to the above statement by (Indrayana, 2013), fartlek is slow running which is then varied with intensive short sprints from medium distance running with a fairly high constant speed then interspersed with sprint running and jogging and sprinting again and so on, so variations in temp running can be played depending on the practical conditions. Nursing diagnosis of activity intolerance is a major problem that occurs in asthma patients. Activity intolerance is the inadequacy of psychological or physiological energy to carry out or complete activities that must / have been carried out.

One outcome that must be achieved in solving this problem is activity tolerance, with the limitation of respiratory status characteristics. In this research, the process of nursing care with Calista Roy's theoretical approach the results of the study showed an increase in the value of the Peak Expiratory Flow and Asthma Control Test (ACT) showed that the goal of nursing care was achieved.

According to Roy, as an open system, humans receive input or stimulus either from the environment or from within themselves, the level of adaptation is determined by a combination of focal, contextual, and residual effects. Adaptation occurs when someone responds positively to environmental changes. This adaptive response enhances the integrity of a person who will lead him to be healthy (Agnihotri, Kant, Mishra, et al., 2016; Soni et al., 2012).

When the body gets an external stimulus in the form of yoga breathing and Endurance Exercise, the body responds. The nurse is the key to ensuring the achievement of the client's adaptation goals. Nursing actions aim to enhance the adaptation of individuals and groups so that they contribute to improving health, quality of life.

\section{Conclusion}

The combination of pranayama yoga practice and endurance training exercise can increase the Peak Expiratory Flow (PEF) and Asthma Control Test (ACT). Based on the results of statistical tests, the combination of pranayama yoga exercises and endurance exercise can increase the peak force of forced exhalation (PEF) by 70,881 (L) and predictive peak flow prediction (\% prediction) by $17.83 \%$ asthma control intervals by $38 \%$ and based on the results of Asthma Control Test (ACT) subjects who experienced an increase in control (partially controlled) asthma were $33(97.1 \%)$, respondents. Pranayama yoga 
and endurance training exercise can be used as an alternative choice in supporting pharmacological therapy to improve PEF and control asthma.

\section{Research Limitations}

In this study subjects used different doses of the drug so that it could affect the value of the Peak Expiratory Flow (PEF) and Asthma Control Test (ACT). Researchers also cannot control all respondent activities and trigger the occurrence of disturbances such as air pollution and irritants as well as the subject's uniformity of age.

\section{References}

Abirami, P., \& Raj, J. (2013). Impact of yoga on blood glucose level among mother with gestational diabetes mellitus at government hospital, Tambaram , Chennai, Tamilnadu. Indian Journal of Health and Wellbeing, 4(1), 99-105.

Agnihotri, S., Kant, S., Kumar, S., Mishra, R., \& Mishra, S. (2016). The assessment of effects of yoga on pulmonary functions in asthmatic patients: A randomized controlled study. Journal of Medical Society, 30(2), 98. https://doi.org/10.4103/0972-4958.182909

Agnihotri, S., Kant, S., Mishra, S. K., \& Singh, R. (2016). Efficacy of yoga in mild to moderate persistent chronic bronchial asthma. Indian Journal of Traditional Knowledge, 15(2), 337-340.

Ahmed, A. Z., Mohamed, D., \& Hashem, S. (2011). Effect of using fartlek exercises on Some physical and physiological variables of football and volleyball players. World Journal of Sport Sciences, 5(4), 225-231. Retrieved December 14, 2019, from https:// idosi.org/wjss/5(4)11/3.pdf

Atmoko, W., Faisal, H. K. P., Bobian, E. T., Adisworo, M. W., \& Yunus Faisal. (2011). Prevalens asma tidak terkontrol dan faktorfaktor yang berhubungan dengan tingkat kontrol asma di poliklinik asma rumah sakit persahabatan, jakarta. (The prevalence of uncontrolled asthma and factors related to the level of asthma control in the asthma polyclinic of Friendship Hospital, Jakarta). $J$ Respir Indo, 31(2), 53-60. Retrieved December 14, 2019, from http:// arsip.jurnalrespirologi.org/wp-content/ uploads/2012/03/april-2011-11-18.pdf

Badan Penelitian dan Pengembangan Kesehatan. (2013). Riset kesehatan dasar (riskesdas) 2013. (Basic health research 2013). Laporan Nasional 2013, 1-384. Retrieved October 4, 2019, from https:// pusdatin.kemkes.go.id/resources/download/ general/Hasil\%20Riskesdas\%202013.pdf

Baines, K. J., Simpson, J. L., Wood, L. G., Scott, R. J., Fibbens, N. L., Powell, H., ... Gibson, P. G. (2014). Sputum gene expression signature of 6 biomarkers discriminates asthma inflammatory phenotypes. Journal of Allergy and Clinical Immunology, 133(4), 997-1007. https://doi.org/10.1016/j. jaci.2013.12.1091

Begum, A., \& Hussain, I. (2013). Effect of fartlek training on selected physical and physiological variables of inter district women athlete s. Journal of Creative Research Thoughts, 1(3), 3-6. Retrieved October 14, 2019, from http://ijcrt.net/ UploadedArticle/15.pdf

Bonura, K. B. (2007). The impact of yoga on psychological health in older adults. ProQuest Dissertations and Theses, 190. https://doi.org/10.1123/jpah.2012-0365

Cebrià I Iranzo, M. D. À., Arnall, D. A., Camacho, C. I., \& Tomás, J. M. (2014). Effects of inspiratory muscle training and yoga breathing exercises on respiratory muscle function in institutionalized frail older adults: A randomized controlled trial. Journal of Geriatric Physical Therapy, 37(2), 65-75. https://doi.org/10.1519/ JPT.0b013e31829938bb

Chandra, F. A. (1994). Respiratory practices in yoga. In B. H. Timmons \& R. Ley (Eds.), Behavioral and psychological approaches to breathing disorders (pp. 221-232). Plenum Press.

Chen, Y.-C., Tsai, J.-C., Liou, Y.-M., \& 
Akbar Nur: The Effect of Combination Pranayama Yoga and Endurance Training Exercise on PEF

Chan, P. (2017). Effectiveness of endurance exercise training in patients with coronary artery disease: A meta-analysis of randomised controlled trials. European Journal of Cardiovascular Nursing, 16(5), 397-408. https://doi.org/10.1177/1474515116684407

Côté, A., Turmel, J., \& Boulet, L. P. (2018). Exercise and Asthma. Seminars in respiratory and critical care medicine, 39(1), 19-28. https://doi.org/10.1055/s-0037-1606215

Cramer, H., Lauche, R., \& Dobos, G. (2014). Characteristics of randomized controlled trials of yoga. BMC Complementary \& Alternative Medicine. $\quad$ https://doi.org/10.1186/14726882-14-328

Cramer, H., Posadzki, P., Dobos, G., \& Langhorst, J. (2014). Yoga for asthma: A systematic review and meta-analysis. Annals of Allergy, Asthma and Immunology, 112(6), 503-510.e5. anai.2014.03.014

Eichenberger, P. A., Diener, S. N., Kofmehl, R., \& Spengler, C. M. (2013). Effects of exercise training on airway hyperreactivity in asthma: A systematic review and metaanalysis. Sports Medicine, 43(11), 11571170. https://doi.org/10.1007/s40279-0130077-2

Fulambarker, A., Farooki, B., Kheir, F., Copur, A. S., Srinivasan, L., \& Schultz, S. (2012). Effect of yoga in chronic obstructive pulmonary disease. American Journal of Therapeutics, 19(2), 96-100. https://doi. org/10.1097/mjt.0b013e3181f2ab86

Ghebre, M. A., Bafadhel, M., Desai, D., Cohen, S. E., Newbold, P., Rapley, L., ... Brightling, C. E. (2015). Biological clustering supports both "dutch" and "british" hypotheses of asthma and chronic obstructive pulmonary disease. Journal of Allergy and Clinical Immunology, 135(1), 63-72.e10. https://doi.org/10.1016/j.jaci.2014.06.035

GINA. (2018). Global Strategy for Asthma Management and Prevention. Retrieved December 1, 2019, from https://ginasthma. org/wp-content/uploads/2019/01/2018-

\section{GINA.pdf}

Grzela, K., Zagorska, W., Krejner, A., Litwiniuk, M., Zawadzka-Krajewska, A., Banaszkiewicz, A., ... Grzela, T. (2015). Prolonged Treatment with Inhaled Corticosteroids does not Normalize High Activity of Matrix Metalloproteinase-9 in Exhaled Breath Condensates of Children with Asthma. Archivum Immunologiae et Therapiae Experimentalis, 63(3), 231-237. https://doi.org/10.1007/s00005-015-0328-z

Hall, J. E. (2015). Guyton and Hall textbook of medical physiology e-Book. Elsevier Health Sciences.

Indrayana, B. (2013). Perbedaan pengaruh latihan interval training dan fartlek terhadap daya tahan kardiovaskular pada atlet junior putra taekwondo wild club Medan 2006/2007. (Differences in the effect of interval training and fartlek on cardiovascular endurance in junior male athletes of Taekwondo Wild Club Medan 2006/2007). Jurnal Cerdas Syifa, 2(1), 1-10. https://doi.org/10.22437/ csp.v1i1.699

Utama, J. E. P. (2018). Kombinasi active cycle breathing technique dan buteyko therapy terhadap PEFR Dan kontrol. [Master's thesis, Universitas Airlangga]. Universitas Airlangga. Retrieved December 4, 2019, from https://repository.unair.ac.id/73360/

Katerine, K., Medison, I., \& Rustam, E. (2014). Hubungan tingkat pengetahuan mengenai asma dengan tingkat kontrol asma. (The relationship between the level of knowledge about asthma and the level of asthma control). Artikel Penelitian, 3(1), 5862. https://doi.org/10.25077/jka.v3i1.27

Khotimah, S. (2013). Endurance Exercise Improves Quality Of Life Better Than Breathing Exercise For Patient With COPD In BP4 Yogyakarta, 1(1), 20-32.

Kristina Zaičenkovienè1, A. S., , Roma Aleksandravičienė1, 2, Stasiulevičienè1, L., \& Lithuanian. (2013). Yoga Practice Has Minor Influence On, i(1), 97-101. 
Kushartanti, M. K. B. M. W. (2013). Pengaruh latihan fartlek dengan treadmill dan lari di lapangan terhadap daya tahan kerdiorespirasi. Jurnal Keolahragaan, 1(1), 2013, 1(3), 72-83. https://doi.org/10.21831/ jk.v1i1.2347

Liu, X.-C., Pan, L., Hu, Q., Dong, W.-P., Yan, J.-H., \& Dong, L. (2014). Effects of yoga training in patients with chronic obstructive pulmonary disease: a systematic review and meta-analysis. Journal of Thoracic Disease, 6(6), 795-802. https://doi.org/10.3978/j. issn.2072-1439.2014.06.05

Moore, W. C., \& Castro, M. (2017). The Many "Buckets" of Severe Asthma: Moving Toward Personalized Management. Journal of Allergy and Clinical Immunology: In Practice, 5(4), 936-937. https://doi. org/10.1016/j.jaip.2017.05.017

Eleckuvan, M. (2014). Effectiveness of fartlek training on maximum oxygen consumption and resting pulse rate. International Journal of Physical Education, 3(1), 3-6. https://doi. org $/ 10.26524 / 14115$

Nizet, T. A. C., Heijdra, Y. F., van den Elshout, F. J. J., van de Ven, M. J. T., Bosch, F. H., Mulder, P. H., \& Folgering, H. T. M. (2009). Respiratory muscle strength and muscle endurance are not affected by acute metabolic acidemia. Clinical Physiology and Functional Imaging, 29(6), 392-399. https:// doi.org/10.1111/j.1475-097X.2009.00878.x

Parmar, J., \& Nagarwala, R. (2014). Effects of pranayama on bronchial asthma. International Journal of Physiology, 2(1), 96. http://dx.doi. $\operatorname{org} / 10.5958 / \mathrm{j} .2320-608 X .2 .1 .021$

Putra, M. M., Sriyono, S., \& Yasmara, D. (2017). Yoga pranayama increase Peak Expiratory Flow (PEF) in patient with asthma. In 8th International Nursing Conference on Education, Practice and Research Development in Nursing. https:// dx.doi.org/10.2991/inc-17.2017.4

Quirt, J., Hildebrand, K. J., Mazza, J., Noya, F., \& Kim, H. (2018). Asthma. allergy, Asthma \& Clinical Immunology, 14(S2), 50. https://doi.org/10.1186/s13223-018-0279-0

Safdar, A., Bourgeois, J. M., Ogborn, D. I., Little, J. P., Hettinga, B. P., Akhtar, M., ... Tarnopolsky, M. A. (2011). Endurance exercise rescues progeroid aging and induces systemic mitochondrial rejuvenation in mtDNA mutator miSafdar, A. et al. 2011. "Endurance Exercise Rescues Progeroid Aging and Induces Systemic Mitochondrial Rejuvenation in mtDNA Mutator Mice." Proce. Proceedings of the National Academy of Sciences, 108(10), 4135-4140. https://doi. org/10.1073/pnas.1019581108.

Shankarappa, V., Prashanth, P., Annamalai, N., \& Varunmalhotra. (2012). The short term effect of pranayama on the lung parameters. Journal of Clinical and Diagnostic Research, 6(1), 27-30.

Shyam Karthik, P., Chandrasekhar, M., Ambareesha, K., \& Nikhil, C. (2014). Effect of pranayama and suryanamaskar on pulmonary functions in medical students. Journal of Clinical and Diagnostic Research, 8(12), BC04-BC06. https://doi.org/10.7860/ JCDR/2014/10281.5344

Sindhu, P. (2015). Panduan lengkap yoga: untuk hidup sehat dan seimbang. (The complete guide to yoga: For a healthy and balanced life.) Mizan Qanita.

Soni, R., Munish, K., Singh, K. P., \& Singh, S. (2012). Study of the effect of yoga training on diffusion capacity in chronic obstructive pulmonary disease patients: A controlled trial. International Journal of Yoga, 5(2), 123-127. https://dx.doi. org/10.4103\%2F0973-6131.98230

Suryantoro, E., Isworo, A., \& Upoyo, A. S. (2017). Perbedaan Efektivitas Pursed Lips Breathing dengan Six Minutes Walk Test terhadap Forced Expiratory. (Differences of Effectiveness of Pursed Lips Breathing and Six Minutes Walk Test against Forced Expiratory). 5, 99-112. https://doi. org/10.24198/jkp.v5i2.448

Udayani, W., \& Amin, M. (2019). The Effect of Combination of Buteyko Breathing 
Akbar Nur: The Effect of Combination Pranayama Yoga and Endurance Training Exercise on PEF

Technique and Walking Exercise on Forced Peak Expiratory Flow In Adult Asthmatic Patients, 7(2). https://doi.org/10.24198/jkp. v7i2.1193

WHO. (2018). WHO | Bronchial asthma. Retrieved November 3, 2018, from http:// www.who.int/mediacentre/factsheets/fs206/ en/

Wijaya, I. M. K. (2015). Aktivitas Fisik (Olahraga) Pada Penderita Asma. (Physical activity (exercise) in asthmatics). 336-341.
Benavides-Pinzón, W. F., \& Torres, J.L. (2017). Effects of yoga ( pranayama ) on lung function and lactate kinetics in sedentary adults at intermediate altitude, 65(3), 467472. https://doi.org/10.15446/revfacmed. v65n3.56310

Yang ZY, Zhong HB, Mao C, Yuan JQ, Huang YF, Wu XY, Gao YM, T. J. (2016). Yoga for asthma ( Review ) Summary Of Findings For The Main Comparison. Cochrane Database of Systematic Reviews, (4). https://doi. org/10.1002/14651858.CD010346.pub2 